\title{
HUBUNGAN ANTARA KOMUNIKASI EFEKTIF DOKTER-PASIEN DENGAN TINGKAT KECEMASAN PADA PASIEN PREOPERASI
}

\author{
Amelia Laksmi Pratita ${ }^{1}$, Iwan Sis Indrawanto ${ }^{2}$, Djaka Handaja ${ }^{3}$
}

Fakultas Kedokteran Universitas Muhammadiyah Malang, J1. Bendungan Sutami 188 A Sumbersari malang, Lowokwaru, Kota Malang, 65145, Indonesia, (0341) 582060

\begin{abstract}
ABSTRAK
Hubungan Antara Komunikasi Efektif Dokter- Pasien dengan Tingkat Kecemasan pada Pasien Preoperasi. Latar Belakang :Kecemasan adalah satu perasaan subjektif yang dialam seseorang terutama oleh adanya pengalaman baru, termasuk pada pasien yang akan mengalami tindakan invasif seperti pembedahan. Kecemasan dapat dikurangi dengan tindakan fokus pada komunikasi efektif dokter-pasien bagi pasien dan keluarganya sebelum dilaksanakan tindakan operasi. Tujuan : untuk mengetahui hubungan antara komunikasi efektif dokter - pasien dengan tingkat kecemasan pada pasien preoperasi di Paviliun Dahlia Dr. H. Koesnadi Bondowoso. Metodologi Penelitian : jenis penelitian observational analitik dengan desain cross sectional, yang dilaksanakan di Paviliun Dahlia RSU dr. H. Koesnadi Bondowoso mulai tanggal 2 januari 2012 sampai dengan 31 januari 2012. Data dikumpulkan dengan cara menyebarkan kuesioner tentang komunikasi efektif dokter-pasien, observasi dan wawancara untuk mengisi check list pada skala HARS sebagai alat ukur tingkat kecemasan pasien, sedangkan untuk mengetahui hubungan antar variabel digunakan uji Spearman. Hasil : Penelitian menghasilkan nilai approx sig pada spearman correlation $=0,000$ lebih kecil dari $\mathrm{p}(0,05)$ yang berarti terdapat hubungan antara tingkat komunikasi dokter-pasien dan tingkat kecemasan. Kesimpulan : Komunikasi efektif dokter-pasien merupakan tindakan yang sangat penting, dimana semakin baik tingkat komunikasi dokter maka semakin menurun tingkat kecemasan pasien.
\end{abstract}

Kata kunci : Komunikasi efektif dokter-pasien, kecemasan.

\section{ABSTRACT}

Relationship Between Effective Communication Doctor-Patient with Anxiety Levels in Preoperative Patients. Background: Anxiety is a subjective feeling experienced by a person primarily by the presence of new experiences, including in patients who will experience such as invasive surgery. Anxiety can be reduced by measures focusing on effective doctor-patient's communication to patients and their family before the procedure performed. Purpose:to prove the relationship between effective doctor-patient's communication with anxiety levels in preoperative patients in the Pavilion Dablia Dr. H. Koesnadi Bondowoso. Method: Analyticalobservational study with cross sectional design, which was held in the Pavilion Dablia RSU dr. H. Koesnadi Bondowoso started 2nd january 2012 to 31th january 2012 Data were collected by distributing questionnaires about effective doctor-patient's communication, observation and interviews to fill the check list at the HARS scale as a tool to measure the anxiety levels of patients, whereas to prove the relationship between the variables used Spearman test. Result : Study on the value of approx sig Spearman correlation $=0.000(p<0.05)$ that means there was a relationship between the level of doctor-patient's communication and the level anxiety. Conclusion: Effective doctorpatient's communication is a very important procedure, in which the more effective the communication levels of doctor,the less of patien's, the less of patien's anxiety levels.

Key words: Effective communication, anxiety.

\section{PENDAHULUAN}

Rumah Sakit merupakan salah satu organisasi penghasil produk jasa pelayanan kesehatan. Sebagai institusi yang bergerak dibidang pelayanan, rumah sakit harus memiliki budaya kerja ramah, sopan, cepat menanggapi kebutuhan pelanggan, dan bersedia melakukan apa yang diperlukan untuk memuaskan pelanggan. Sukses suatu rumah sakit lebih bertanggung jawab pada kemampuan sikap atau perilaku para karyawannya dari pada faktor yang lain (Depkes, 2002).

Pelayanan kesehatan yang dilakukan di Rumah Sakit meliputi pencegahan, pengobatan penyakit, promosi kesehatan dan pemulihan atau rehabilitatif (Widodo, 1999).
Salah satu layanan pengobatan yang ada di Rumah Sakit adalah operasi. Sampai saat ini sebagian besar orang beranggapan bahwa operasi merupakan pengalaman yang menakutkan. Reaksi cemas ini akan berlanjut bila pasien tidak pernah atau kurang mendapat informasi yang berhubungan dengan penyakit dan tindakan yang dilakukan terhadap dirinya. Setiap orang pernah mengalami periode cemas, apalagi pasien yang akan menjalani operasi. Kecemasan merupakan gejala klinis yang terlihat pada pasien dengan penatalaksanaan medis. Bila kecemasan pada pasien pre operasi tidak segera diatasi maka dapat mengganggu proses penyembuhan, untuk itu pasien yang akan menjalani operasi harus diberi pendidikan kesehatan untuk menurunkan atau mengurangi gejala kecemasan (Carbonel, 2002). 
Dalam profesi kedokteran, komunikasi dokter -pasien merupakan salah satu kompetensi yang harus dikuasai dokter. Kompetensi komunikasi menentukan keberhasilan dalam membantu penyelesaian masalah kesehatan pasien. Selama ini kompetensi komunikasi dapat dikatakan terabaikan, baik dalam pendidikan maupun dalam praktik kedokteran/ kedokteran gigi (KKI) . Dalam buku manual komunikasi dokter-pasien yang dikeluarkan oleh Konsil Kedoktearan Indonesia mengatakan bahwa, " Di Indonesia sebagian dokter merasa tidak mempunyai waktu yang cukup untuk berbincang-bincang dengan pasiennya, sehingga hanya bertanya seperlunya. Akibatnya, dokter bisa saja tidak mendapatkan keterangan yang cukup untuk menegakkan diagnosis dan menentukan perencanaan dan tindakan lebih lanjut. Dari sisi pasien, umumnya pasien merasa dalam posisi lebih rendah di hadapan dokter (superiorinferior), sehingga takut bertanya dan bercerita atau hanya menjawab sesuai pertanyaan dokter saja." Komunikasi yang baik dan berlangsung dalam kedudukan setara (tidak superior-inferior) sangat diperlukan agar pasien mau/dapat menceritakan sakit/keluhan yang dialaminya secara jujur dan jelas. Komunikasi efektif mampu mempengaruhi emosi pasien dalam pengambilan keputusan tentang rencana tindakan selanjutnya, sedangkan komunikasi tidak efektif akan mengundang masalah, dalam sebuah studi yang dilakukan di Australia menyebutkan bahwa 1- $22 \%$ komplain pasien berkaitan dengan komunikasi yang kurang adekuat (Feri.Y 2006).

Banyak penelitian telah membuktikan bahwa pasien yang menyatakan persetujuan karena pengetahuan dan pemahamannya akan informasi yang diberikan kepadanya, akan memperlihatkan hasil yang lebih baik dari pada sebaliknya." a well informed patient make a better patient than one who is misinformed or not informed at all. Kuzl (2004), dalam penelitiannya mengemungkakan pasien lebih peduli pada komunikasi yang baik dengan dokternya, dan ternyata sebagian besar error disebabkan oleh kesalahpahaman interpretasi atas komunikasi dokter. Dari 121 pasien yang diwawancarai dalam penelitian Kuzl, $70 \%$ pasien merasakan adanya ketidaknyamanan psikologis/komunikasi (Fery.Y.2006).

Beberapa penelitian yang terkait diantaranya Tanjung (2005) tentang efek komunikasi terapeutik terhadap tingkat kecemasan pasien pre operasi di Rumah Sakit Haji Adam Malik menunjukkan bahwa sebanyak $84,6 \% \%$ responden mengalami kecemasan ringan dan $15,4 \%$ mengalami kecemasan sedang dan tidak ada pasien dengan tingkat kecemasan berat maupun panik sebelum pelaksanaan treatment (komunikasi terapeutik). Setelah pelaksanaan komunikasi terapeutik $92,3 \%$ pasien preoperasi tingkat kecemasannya menjadi ringan dan hanya $7,7 \%$ tingkat kecemasannya menjadi sedang. Penelitian ini menunjukkan bahwa komunikasi terapeutik mempunyai pengaruh yang signifikan dalam menurunkan kecemasan klien. Penelitian Rini (2006), tentang Hubungan Tingkat Kecemasan Dengan Propil Tekanan Darah Pada Pasien Pre Operasi Tur Of Prostat Di Instalasi Bedah Sentral RSUD.dr.Moewardi Surakarta, yang menyimpulkan adanya hubungan yang bermakna antara kecemasan dengan propel tekanan darah pada pasien pre operasi tur of prostat. Demikian juga Triana
(2010) dalam hasil penelitiannya didapatkan bahwa Terdapat hubungan yang kuat pengetahuan tentang Penyakit Jantung Koroner (PJK) terhadap tingkat kecemasan klien PJK di ruang rawat inap RSU dr.H. Koesnadi Bondowoso Komunikasi efektif diharapkan dapat mengatasi kendala yang ditimbulkan oleh kedua pihak, pasien dan dokter. Dokter dapat mengetahui dengan baik kondisi pasien dan keluarganya, dan pasien pun percaya sepenuhnya kepada dokter sehingga dapat menurunkan kecemasan pasien. Kondisi ini amat berpengaruh pada proses penyembuhan pasien selanjutnya. Pasien merasa tenang dan aman ditangani oleh dokter sehingga akan patuh menjalankan petunjuk dan nasihat dokter karena yakin bahwa semua yang dilakukan adalah untuk Kepentingan dirinya. Pasien percaya bahwa dokter tersebut dapat membantu menyelesaikan masalah kesehatannya. Oleh karena itu, penulis merasa perlu dilakukan penelitian tentang hubungan antara komunikasi efektif dokter- pasien dengan tingkat kecemasan pada pasien preoperasi di Paviliun Dahlia RSU dr. H. Koesnadi Bondowoso.

\section{METODE}

Penelitian ini menggunakan jenis penelitian observational analitik dengan desain cross sectional. Lokasi penelitian ini bertempat di bagian Paviliun Dahlia RSU dr. H. Koesnadi Bondowoso. Penelitian akan dilakukan pada bulan Januari 2012.

Pada penelitian ini populasinya adalah semua pasien yang akan dilakukan operasi di Paviliun Dahlia RSU dr. H. Koesnadi Bondowoso. Pada penelitian ini sampel yang diambil adalah semua dari pasien preoperasi di Paviliun Dahlia RSU dr. H. Koesnadi Bondowoso, yang memenuhi kriteria inklusi. Dalam penelitian ini pengambilan sampel dengan non random sampling dengan teknik pengambilan sampel dengan menggunakan total sampling, dengan kriteria inklusi semua pasien yang akan dilakukan operasi di RSU dr. H. Koesnadi Bondowoso sejak bulan Januari 2012, bersedia menjadi responden. Kriterian Eksklusi berupa pasien yang mengalami atau terdiagnosi gangguan jiwa serius. (GMO, skizofrenia, depresi, gangguan cemas). pasien mengalami gangguan fisik serius diluar masalah operasi (contoh : Stroke, Diabetes Melittus,Thyroid,dll).

Variabel bebas yaitu Komunikasi Efektif dokter-Pasien, variabel tergantung: Tingkat Kecemasan Dalam pelaksanaan penelitian ini, peneliti mendapat rekomendasi dari Institusi untuk melakukan pengumpulan data. Sebelum dilakukan penelitian ini, peneliti terlebih dahulu mengajukan permohonan ijin kepada Direktur dan Kepala Ruang serta kepada pihak terkait lainnya di Paviliun Dahlia RSU.dr.H. Koesnadi Bondowoso. Kemudian peneliti menyeleksi responden sesuai dengan kriteria inklusi. Selanjutnya peneliti akan menyebarkan kuesioner ke subyek yang diteliti. Pengumpulan data penelitian ini dalam variabel independen untuk mengetahui komunikasi efektif yang dilakukan dokter dan pada variabel dependen untuk mengetahui tingkat kecemasan klien dengan observasi menggunakan alat ukur skala HARS.

Pasien Pre Operasi yang dirawat inap di Paviliun Dahlia RSU dr.H.Koesnadi Bondowoso, diberi penjelasan tentang 
tujuan penelitian. Jika pasien bersedia menjadi responden, peneliti memberikan kuesioner dan penjelasan tentang cara pengisiannya, mulai dari lembar persetujuan sampai dengan cara menjawab pertanyaan. Saat responden mengisi kuesioner, responden akan didampingi oleh peneliti atau perawat di ruang rawat inap yang telah menerima pendelegasian dari peneliti, yang sebelumnya telah dilakukan briefing untuk menciptakan persamaan persepsi. Kuesioner yang telah diisi oleh responden dikoreksi oleh peneliti dan diberi nilai atau skor, kemudian dicatat dan didokumentasikan untuk persiapan analisa data.

Tekhnik pengolahan data dengan tahapan sebagai berikut : Editing yang bertujuan untuk meneliti kembali isian kuesioner atau instrumen penelitian lainnya dan hal-hal yang harus diperhatikan dalam mengedit terhadap kelengkapan jawaban dan keseragaman satuan ukuran. Coding dan scoring Untuk variabel bebas : menggunakan alat ukur kuesioner dengan skala ordinal untuk jawaban tidak sama sekali diberi skor 0,kurang diberi skor 1 , sedang diberi skor 2, cukup baik diberi skor 3 dan jawaban baik diberi skor 4, kemudian dijumlahkan dan dibandingkan dengan skor tertinggi dikalikan $100 \%$. Rumus yang digunakan menurut Arikunto (2006), adalah Rumus : N= Sp/Smx100\% dengan keterangan $\mathrm{N}$ : nilai, Sp: skor yang didapat responden, Sm: skor maksimum yang diharapkan.

Hasil prosentase dari cara pemberian skor dan penilaian diinterprestasikan dengan skala kualitatif (Arikunto, 2002). Skor yang digunakan untuk mempermudah dalam mengkategorikan jenjang/peringkat dalam penelitian dituliskan dalam prosentase komunikasi dilakukan baik persentase 76-100\%, komunikasi dilakukan cukup persentase $56-75 \%$, komunikasi dilakukan kurang persentase $<56 \%$. Untuk kategori komunikasi dilakukan baik diberi skor 3, komunikasi dilakukan cukup diberi skor 2 dan yang komunikasi dilakukan kurang diberi skor 1.

Berdasarkan hasil validitas dari 14 pertanyaan, pada kolom corrected item- total correlation, semua nilainya positif dan lebih dari $r$ tabel, maka semua pertanyaan pada kuisioner adalah valid yaitu dengan $\mathrm{r}$ tabel $=0,2653$. Pada uji reliabilitas nilai Cronbach's alpha $=0,349$ lebih besar dari pada $\mathrm{r}$ tabel $=0,2653$ yang berarti bahwa kuisioner tersebut reliabel. Untuk variabel tergantung : tingkat kecemasan menggunakan skala Hamilton Anxiety Rating Scale (HARS), yang digolongkan dalam tingkat kecemasan yaitu $<14=$ tidak ada kecemasan, $14-20=$ kecemasan ringan, $21-27=$ kecemasan sedang, $28-41=$ kecemasan berat, $42-56=$ kecemasan berat sekali atau panic.

Berdasarkan hasil scoring data dilakukan tabulasi data dengan menggunakan tabel distribusi frekuensi untuk menginterpretasi karakteristik dari masing-masing variabel.

Dalam penelitian ini analisa data menggunakan korelasi Spearman Rank (Rho) dilakukan secara komputerisasi dengan menggunakan program SPSS (Statistical Product and Service Solution) windows versi 17.0. Ada tidaknya korelasi dinyatakan sebagai koefisien korelasi yang didapat nilai kemaknaan $\mathrm{p}=(0,05)$. Jika hasil analisis $\mathrm{p}<0,05$ maka hipotesa diterima atau tingkat pengetahuan berpengaruh terhadap tingkat kecemasan pasien.

\section{HASIL DAN PEMBAHASAN}

Penelitian dilakukan terhadap 40 pasien pre operasi di Paviliun Dahlia RSU.dr.H.Koesnadi, sesuai dengan kriteria inklusi. Data diperoleh berdasarkan hasil jawaban kuesioner untuk mengetahui tentang komunikasi dokter-pasien yang diberikan kepada responden dan untuk mengetahui tingkat kecemasan pasien preoperasi pada responden tersebut. Data diolah sesuai dengan tujuan penelitian untuk mengetahui hubungan antara komunikasi efektif dokter-pasien dengan tingkat kecemasan pasien pre operasi di Paviliun Dahlia RSU.dr.H.Koesnadi. Data di bawah ini merupakan deskripsi jawaban responden atas pertanyaan- pertanyaan dalam kuesioner komunikasi efektif dokter-pasien. berdasarkan item instrumen dari komunikasi efektif dokter-pasien, dapat diketahui mengenai komunikasi efektif dokter-pasien yang diberikan terhadap pasien pre operasi di Paviliun Dahlia RSU.dr.H.Koesnadi, yang secara keseluruhan yang dapat disajikan sebagai berikut.

\begin{tabular}{|c|c|c|}
\hline $\mathbf{N}$ & Instrumen komunikasi & $\begin{array}{llll}\text { Skor 0 } & \text { Skor 1 } & \text { Skor 2 } & \text { Skor 3 } \\
\end{array}$ \\
\hline $\mathbf{U}$ & & 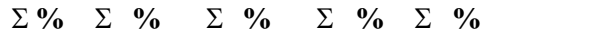 \\
\hline 1 & $\begin{array}{l}\text { Menyampaikan informasi } \\
\text { tentang penyakit }\end{array}$ & $\begin{array}{lllllllll}0 & 0 \% & 6 & 15 \% & 1 & 2,5 \% & 13 & 32,5 \% 20 & 50 \% \\
\end{array}$ \\
\hline 2 & Tentang tujuan operasi & 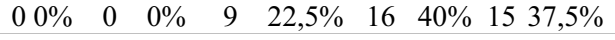 \\
\hline 3 & $\begin{array}{l}\text { Menjelaskan tentang } \\
\text { prosedur operasi }\end{array}$ & $\begin{array}{llllllll}12,5 \% 2 & 5 \% & 5 & 12,5 \% & 12 & 30 \% & 20 & 50 \% \\
\end{array}$ \\
\hline 4 & $\begin{array}{l}\text { Menjelaskan tentang obat- } \\
\text { obatan yang akan } \\
\text { digunakan pada saat operasi } \\
\text { dan efek samping yang } \\
\text { timbul }\end{array}$ & $\begin{array}{lllllllll}25 \% & 10 & 25 \% & 3 & 7,5 \% & 12 & 30 \% & 13 & 32,5 \%\end{array}$ \\
\hline 5 & $\begin{array}{l}\text { Tentang kemungkinan } \\
\text { keberhasilan tindakan } \\
\text { operasi }\end{array}$ & 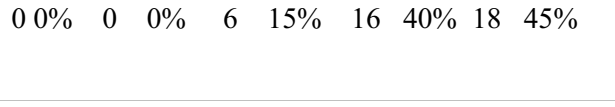 \\
\hline 6 & $\begin{array}{l}\text { Tentang kemungkinan } \\
\text { komplikasi setelah operasi }\end{array}$ & $\begin{array}{lllllllll}25 \% & 1 & 2,5 \% & 2 & 5 \% & 17 & 42,5 \% 18 & 45 \% \\
\end{array}$ \\
\hline 7 & $\begin{array}{l}\text { Tentang perilaku yang } \\
\text { harus dilakukan oleh pasien } \\
\text { setelah tindakan operasi }\end{array}$ & 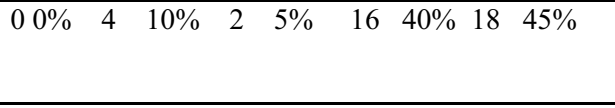 \\
\hline 8 & $\begin{array}{l}\text { Melibatkan pasien dan } \\
\text { keluarga dalam rencana } \\
\text { perawatan atau } \\
\text { pengambilan keputusan }\end{array}$ &  \\
\hline
\end{tabular}




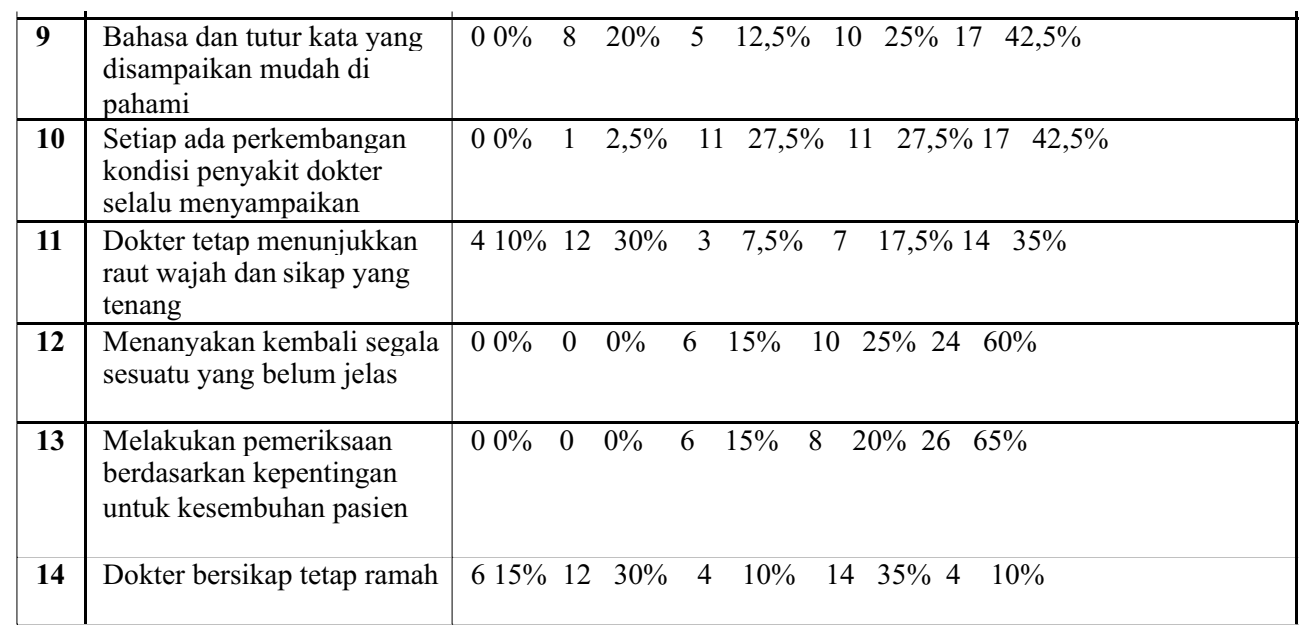

Keterangan skor: 0 : tidak sama sekali, 1 : kurang, 2 : sedang, 3 : cukup baik, 4 : baik

Berdasarkan tabel 5.1, didapatkan hasil bahwa komunikasi efektif dokter- pasien dengan kategori baik yaitu komunikasi tentang menyampaikan informasi tentang penyakit sebagian besar $50 \%$ dokter menyampaikan dengan baik, komunikasi tentang prosedur operasi sebagian besar $50 \%$ dokter menyampaikan dengan baik, komunikasi tentang menjelaskan obat-obatan yang akan digunakan pada saat operasi dan efek samping yang timbul sebagian besar 32,5\% dokter menyampaikan dengan baik, komunikasi tentang kemungkinan keberhasilan tindakan operasi sebagian besar $45 \%$ dokter menyampaikan dengan baik, komunikasi tentang kemungkinan komplikasi setelah operasi sebagian besar $45 \%$ dokter menyampaikan dengan baik, komunikasi tentang perilaku yang harus dilakukan oleh pasien setelah tindakan operasi sebagian besar $45 \%$ dokter menyampaikan dengan baik, komunikasi tentang melibatkan pasien dan keluarga dalam rencana perawatan atau pengambilan keputusan sebagian besar 62,5\% dokter menyampaikan dengan baik, komunikasi tentang bahasa dan tutur kata yang disampaikan mudah di pahami sebagian besar $42,5 \%$ dokter menyampaikan dengan baik, komunikasi tentang setiap ada perkembangan kondisi penyakit dokter selalu menyampaikan sebagian besar 42,5\% dokter menyampaikan dengan baik, komunikasi tentang tetap menunjukkan raut wajah dan sikap yang tenang sebagian besar 35\% dokter menyampaikan dengan baik, komunikasi tentang menanyakan kembali segala sesuatu yang belum jelas sebagian besar $60 \%$ dokter menyampaikan dengan baik, komunikasi tentang melakukan pemeriksaan berdasarkan kepentingan untuk kesembuhan pasien sebagian besar 65\% dokter menyampaikan dengan baik. Sedang kategori komunikasi efektif dokter-pasien dengan kategori cukup baik yaitu komunikasi tentang tujuan operasi sebagian besar $40 \%$ dokter menyampaikan tujuan operasi dengan cukup baik dan komunikasi tentang bersikap tetap ramah sebagian besar 35\% dokter menyampaikan dengan cukup baik Selanjutnya berdasarkan ke-14 item instrumen dari komunikasi efektif dokter-pasien, dapat diketahui mengenai penerapan komunikasi efektif dokterpasien pada pasien preoperasi di Paviliun Dahlia RSU.dr.H.Koesnadi, yang secara keseluruhan menurut hasil penelitian yang telah dilakukan terhadap 40 pasien pre operasi di Paviliun Dahlia RSU.dr.H.Koesnadi dapat dilihat bahwa didapatkan penerapan komunikasi yang paling banyak yaitu cukup sebanyak 21 orang $(52,5 \%)$.Pada pasien preoperasi di paviliun dahlia RSU.dr.H.Koesnadi sebagian besar penerapan komunikasi dokter-pasien cukup. Tingkat Kecemasan Pasien Preoperasi Data di bawah ini merupakan deskripsi jawaban responden atas pertanyaan-pertanyaan dalam kuesioner berdasarkan ke-14 item instrumen dari gejala kecemasan yang diukur dengan Hamilton Anxiety Rating Scale (HARS) di atas, dapat diketahui mengenai tingkat kecemasan pasien pre-operasi di Paviliun Dahlia RSU.dr.H. Koesnadi, yang secara keseluruhan didapatkan hasil responden yang mengalami gejala kecemasan ringan dengan persentase terbesar berupa ansietas (65\%), ketegangan $60 \%$, gangguan tidur $(65 \%)$ gangguan kecerdasan $(57,5 \%)$, perasaan depresi $(57,5 \%)$, gejala kardiovaskular $(60 \%)$ dan gejala autonom $(67,5 \%)$. Sedangkan responden tidak mengalami kecemasan dengan presentase terbesar berupa tidak adanya ketakutan $(65 \%)$, tidak ada gejala somatic sensorik $(75 \%)$, tidak ada gejala respiratorik $(80 \%)$, tidak ada gejala gastrointestinal $(67,5 \%)$, tidak ada gejala urogenital $(62,5 \%)$, dan tingkah laku (sikap) pada wawancara $(53,5$ $\%)$.

Selanjutnya berdasarkan ke-14 item instrumen dari gejala kecemasan yang diukur dengan Hamilton Anxiety Rating Scale (HARS) di atas, dapat diketahui mengenai tingkat kecemasan pada pasien preoperasi di Paviliun Dahlia RSU.dr.H.Koesnadi, yang secara keseluruhan menurut hasil penelitian yang telah dilakukan terhadap 40 pasien pre operasi di Paviliun Dahlia RSU.dr.H.Koesnadi, menunjukkan bahwa tingkat kecemasan pasien preoperasi yang paling banyak yaitu responden yang mempunyai tingkat kecemasan yang tergolong sedang sebanyak 17 orang $(42,5 \%)$. Berdasarkan data di atas menunjukkan bahwa pada pasien pre-operasi di Paviliun Dahlia RSU.dr.H.Koesnadi mayoritas mengalami tingkat kecemasan yang tergolong sedang.

Hubungan Antara Komunikasi Efektif Dokter-Pasien Dengan Tingkat Kecemasan Pasien Preoperasi Di Paviliun Dahlia RSU.Dr.H.Koesnadi Untuk mengetahui adanya hubungan antara komunikasi efektif dokter-pasien dengan tingkat kecemasan pasien pre operasi di Paviliun Dahlia RSU.dr.H.Koesnadi, maka perlu dibentuk tabulasi silang (crosstabs) yang dapat menggambarkan penyebaran data secara lebih terinci, sebagaimana disajikan pada tabel berikut. 
Pada tabel menunjukkan bahwa 21 pasien yang mendapatkan komunikasi efektif dokter-pasien yang cukup sebagian besar mengalami tingkat kecemasan sedang sebanyak 17 orang (81\%). Dari 19 pasien yang mendapatkan komunikasi efektif dokter-pasien yang baik sebagian besar mengalami tingkat kecemasan ringan sebanyak 10 orang (52.6\%). Sehingga dapat dikatakan bahwa dimana semakin baik tingkat komunikasi dokter maka semakin menurun tingkat kecemasan pasien preoperasi. Adanya kaitan antara tingkat komunikasi dokter dan tingkat kecemasan pasien preoperasi di Paviliun Dahlia RSU.dr.H. Koesnadi dapat diketahui bahwa dimana semakin baik tingkat komunikasi dokter-pasien maka semakin menurun tingkat kecemasan pasien preoperasi di Paviliun Dahlia RSU.dr.H. Koesnadi, dibandingkan dengan mereka yang memiliki tingkat kecemasan yang sedang.

Analisis Data Dengan Menggunakan Uji Korelasi Rank Spearman Uji Korelasi Rank Spearman digunakan untuk menguji adanya hubungan antara komunikasi efektif dokter-pasien dengan tingkat kecemasan pasien pre operasi di Paviliun Dahlia RSU.dr.H.Koesnadi seperti uji korelasi Rank Spearman menunjukkan bahwa nilai approx sig pada spearman correlation $=0,000$ lebih kecil dari $\mathrm{p}(0,05)$ yang berarti terdapat hubungan antara tingkat komunikasi dokter-pasien dan tingkat kecemasan pasien preoperasi di Paviliun Dahlia RSU.dr.H.Koesnadi , dimana semakin baik tingkat komunikasi dokter maka semakin menurun tingkat kecemasan pasien preoperasi.Hal ini ditunjukkan dengan nilai R Spearman $-0,854$.

Penelitian ini dilakukan untuk menggambarkan dan mengetahui adanya hubungan antara hubungan antara komunikasi efektif dokter-pasien dengan tingkat kecemasan pasien pre operasi di Paviliun Dahlia RSU.dr.H. Koesnadi Sampel yang digunakan dalam penelitian ini adalah semua dari pasien preoperasi di Paviliun Dahlia RSU dr. H. Koesnadi Bondowoso, sesuai dengan kriteria yang telah ditentukan dan diperoleh 40 orang sampel yang bersedia menjadi responden dalam penelitian ini.

Berdasarkan hasil penelitian didapatkan penerapan komunikasi yang paling banyak yaitu cukup sebanyak 21 orang $(52,5 \%)$. Dalam distribusi frekuensi jawaban responden tentang komunikasi efektif dokter-pasien menunjukkan hasil bahwa dalam komunikasi tentang tujuan operasi dan tentang dokter bersikap tetap ramah medapatkan hasil yang cukup baik yaitu sebesar $35 \%$ dan $40 \%$ sedangkan untuk prosedur operasi yang lain mendapatkan hasil yang baik walaupun hasil yang didapatkan prosentasenya masih banyak yang dibawah 50\% namun hal tersebut masih dapat dikategorikan sebagai komunikasi efektif yang baik.

Seyogyanya kedua hal tentang tujuan operasi dan tentang dokter bersikap tetap ramah mendapatkan hasi baik karena kedua hal tersebut berkaitan dengan unsurunsur yang perlu diinformasikan meliputi prosedur yang akan dilakukan, risiko yang mungkin terjadi, manfaat dari tindakan yang akan dilakukan, dan alternatif tindakan yang dapat dilakukan. Di samping itu perlu diinformasikan pulakemungkinan yang dapat timbul apabila tindakan tidak dilakukan, juga kemungkinan (prognosis) atau perjalanan penyakit yang diderita dan dalam hal pasien berhak mendapatkan informasi mengenai perkiraan biaya pengobatannya (Kurzt 1998).
Selain faktor diatas komunikasi efektif juga dipengaruhi faktor jenis komunikasi (lisan, tulisan/verbal, non-verbal), menjadi pendengar yang baik (active listener), faktor adanya penghambat proses komunikasi (noise), faktor pemilihan alat penyampai pikiran atau informasi yang tepat (channe), mengenal tentang mengekspresikan perasaan dan emosi serta faktor dari penerima pesan yaitu pasien sebagai receiver dipengaruhi oleh perbedaan sudut pandang, pengetahuan atau pengalaman, perbedaan budaya, masalah bahasa, dan lainnya (Hardjana 2003).

Hal ini sesuai dengan penelitian Feri.Y (2006) Komunikasi efektif mampu mempengaruhi emosi pasien dalam pengambilan keputusan tentang rencana tindakan selanjutnya, sedangkan komunikasi tidak efektif akan mengundang masalah, dalam sebuah studi yang dilakukan di Australia menyebutkan bahwa 13 - $22 \%$ komplain pasien berkaitan dengan komunikasi yang kurang adekuat Dokter mempunyai peranan yang sangat penting dalam setiap tindakan pembedahan baik pada masa sebelum, selama maupun setelah operasi. Intervensi pembedahan yang tepat diperlukan untuk mempersiapkan klien baik secara fisik maupun psikis. Tingkat keberhasilan pembedahan sangat tergantung pada setiap tahapan yang dialami dan saling ketergantungan antara tim kesehatan yang terkait (dokter bedah, dokter anestesi dan perawat) disamping peranan pasien yang kooperatif selama proses preoperatif. Oleh sebab itu perlu peran dokter untuk mengevaluasi pemahaman pasien mengenai prosedur pre operatif dengan tingkat komunikasi efektif dokter-pasien itu sendiri.

Sedangkan dalam tingkat kecemasan menunjukkan bahwa tingkat kecemasan pasien preoperasi yang paling banyak yaitu responden yang mempunyai tingkat kecemasan yang tergolong sedang sebanyak 17 orang (42,5\%). Hal ini dikarenakan karena tindakan operasi atau pembedahan merupakan pengalaman yang bisa menimbulkan kecemasan dan kecemasan biasanya berhubungan dengan segala macam prosedur asing yang harus dijalani pasien dan juga ancaman terhadap keselamatan jiwa akibat prosedur pembedahan dan tindakan pembiusan sehingga hasil yang didapatkan yaitu kecemasan yang tergolong sedang. Distribusi frekuensi jawaban responden tentang tingkat kecemasan pasien preoperasi responden dalam aspek psikologis disini terdapat yang mengalami gejala kecemasan ringan dengan persentase terbesar berupa ansietas (65\%), ketegangan $60 \%$, gangguan kecerdasan $(57,5 \%)$, perasaan depresi $(57,5 \%)$,serta terdapat satu tidak terdapat kecemasan berupa tidak adanya ketakutan $(65 \%)$. Sedangkan pada aspek fisiologis responden yang mengalami kecemasan ringan yaitu gangguan tidur (65\%), gejala kardiovaskular $(60 \%)$ dan gejala autonom (67,5\%), serta yang tidak mengalami kecemasan dengan presentase terbesar tidak ada gejala somatic sensorik $(75 \%)$, tidak ada gejala respiratorik $(80 \%)$, tidak ada gejala gastrointestinal $(67,5 \%)$, tidak ada gejala urogenital $(62,5 \%)$, dan tingkah laku (sikap) pada wawancara $(53,5 \%)$. Hal ini dikarenakan kecemasan pasien pre operatif disebabkan berbagai faktor, salah satunya adalah faktor pengetahuan dan sikap dokter dalam memberikan komunikasi efektif serta mengaplikasikan pencegahan kecemasan pada pasien pre operatif. Respon psikologis secara umum berhubungan adanya kecemasan menghadapi anestesi, diagnosa penyakit yang belum pasti, 
keganasan, nyeri, ketidaktahuan tentang prosedur operasi dan sebagainya. Maka seringkali pasien menunjukkan sikap yang agak berlebihan dengan kecemasan yang dialami (Nursalam 2003).

Hasil penelitian di atas sesuai dengan penelitian Tanjung (2005) tentang efek komunikasi terapeutik terhadap tingkat kecemasan pasien pre operasi di Rumah Sakit Haji Adam Malik menunjukkan bahwa sebanyak $84,6 \% \%$ responden mengalami kecemasan ringan dan $15,4 \%$ mengalami kecemasan sedang dan tidak ada pasien dengan tingkat kecemasan berat maupun panik sebelum pelaksanaan treatment (komunikasi terapeutik). Setelah pelaksanaan komunikasi terapeutik $92,3 \%$ pasien preoperasi tingkat kecemasannya menjadi ringan dan hanya $7,7 \%$ tingkat kecemasannya menjadi sedang. Penelitian ini menunjukkan bahwa komunikasi terapeutik mempunyai pengaruh yang signifikan dalam menurunkan kecemasan pasien. Pasien yang mengalami kecemasan menunjukkan gejela mudah tersinggung, susah tidur, gelisah, lesu, mudah menangis dan tidur tidak nyenyak. Menurut Carpenito (1999), menyatakan $90 \%$ pasien preoperatif berpotensi mengalami kecemasan. Manifestasi yang khas pada pasien pre operatif tergantung pada setiap individu dan dapat meliputi menarik diri, membisu, mengumpat, mengeluh dan menangis.

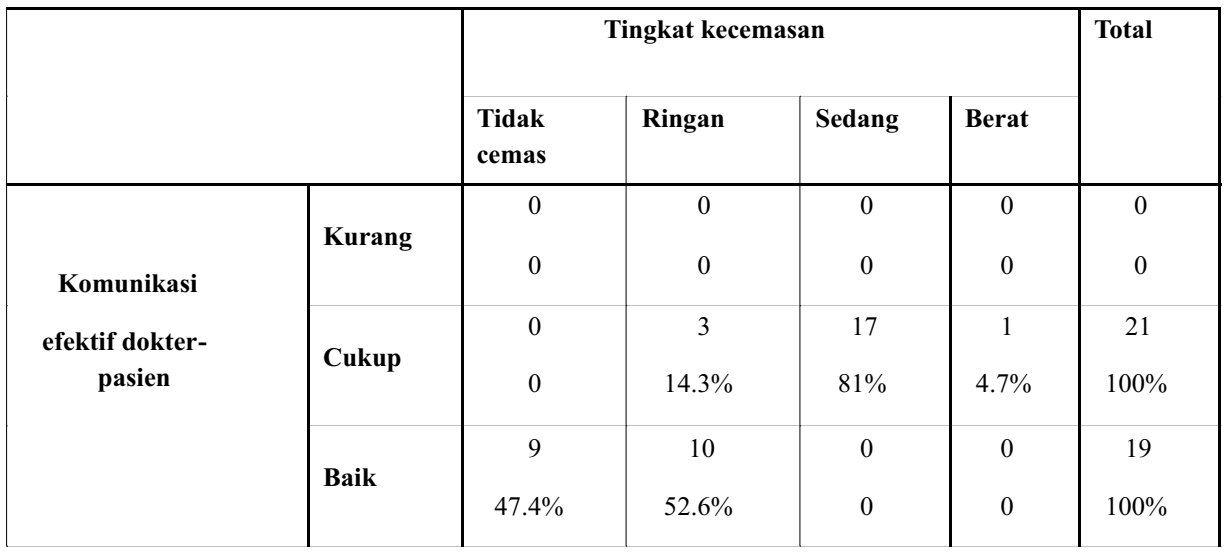

Berdasarkan tabel silang menunjukkan bahwa 21 pasien yang mendapatkan komunikasi efektif dokter-pasien yang cukup sebagian besar mengalami tingkat kecemasan sedang sebanyak 17 orang (81\%). Dari 19 pasien yang mendapatkan komunikasi efektif dokter-pasien yang baik sebagian besar mengalami tingkat kecemasan ringan sebanyak 10 orang (52.6\%). Sehingga dapat dikatakan bahwa dimana semakin baik tingkat komunikasi dokter maka semakin menurun tingkat kecemasan pasien preoperasi.

Hal ini juga didukung oleh hasil pengujian dengan uji korelasi rank spearman yang menunjukkan bahwa nilai approx sig pada spearman correlation $=0,000$ lebih kecil dari $\mathrm{p}(0,05)$ yang berarti terdapat hubungan antara tingkat komunikasi dokter-pasien dan tingkat kecemasan pasien preoperasi di Paviliun Dahlia RSU.dr.H.Koesnadi, dimana semakin baik tingkat komunikasi dokter maka semakin menurun tingkat kecemasan pasien preoperasi di Paviliun Dahlia RSU.dr.H.Koesnadi Bondowoso. Hal ini ditunjukkan dengan nilai R Spearman - 0,854.

Menurut penelitian yang telah dilakukan pemberian komunikasi efektif dokter-pasien pada pasien pre operasi di Paviliun Dahlia RSU.dr.H.Koesnadi merupakan suatu komunikasi antara dokter dengan pasien yang membahas tentang apa yang akan dan tidak akan dilakukan terhadap pasien serta mencakup tujuan, cara kerja, kegunaan dan juga kemungkinan risiko yang terjadi akibat suatu proses atau tindakan diambil. Hasil penelitian di atas sesuai dengan pendapat Triana (2010) komunikasi efektif dapat mengatasi kendala yang ditimbulkan oleh kedua pihak, pasien dan dokter. Dokter dapat mengetahui dengan baik kondisi pasien dan keluarganya, dan pasien pun percaya sepenuhnya kepada dokter sehingga dapat menurunkan kecemasan pasien. Kondisi ini amat berpengaruh pada proses penyembuhan pasien selanjutnya. Pasien merasa tenang dan aman ditangani oleh dokter sehingga akan patuh menjalankan petunjuk dan nasihat dokter karena yakin bahwa semua yang dilakukan adalah untuk kepentingan dirinya.

Pasien percaya bahwa dokter tersebut dapat membantu menyelesaikan masalah kesehatannya. Sehingga semakin baik tingkat komunikasi dokter maka semakin menurun tingkat kecemasan pasien preoperasi sama seperti hasil penelitian diatas bahwa komunikasi efektif mempunyai peranan penting dalam tingkat kecemasan pasien preoperasi di Paviliun Dahlia RSU.dr.H.Koesnadi.

Peneliti menyadari bahwa dalam persiapan dan pelaksanaan penelitian ini masih banyak di jumpai kekurangan dan keterbatasan. Dalam penelitian ini keterbatasan yang di hadapi adalah penelitian ini mempunyai keterbatasan dalam mengetahui faktor-faktor untuk mengukur tingkat kecemasan yang terjadi pada pasien preoperasi selain dari komunikasi efektif dokter-pasien itu sendiri seperti faktor eksternal (ancaman integritas diri dan ancaman sistem diri) dan faktor internal (potensi stressor, maturitas, pendidikan, status ekonomi, keadaan fisik, tipe kepribadian, lingkungan dan situasi, usia, jenis kelamin) terjadinya kecemasan tidak diperhitungkan., peneliti menyadari banyaknya kekurangan pada penelitian ini, sehingga diharapkan untuk peneliti selanjutnya dapat menyempurnakan penelitian ini pada tingkat yang lebih luas dan dapat memberikan hasil yang maksimal.

\section{SIMPULAN}

Berdasarkan hasil penelitian yang telah dilakukan, maka dapat ditarik kesimpulan ada hubungan yang signifikan (bermakna) antara komunikasi efektif dokter- pasien dengan 
tingkat kecemasan pasien pre operasi di Paviliun Dahlia RSU.dr.H.Koesnadi (spearman correlation $=0,000$ lebih kecil dari p $(0,05))$,dimana semakin baik penerapan komunikasi efektif dokter-pasien maka semakin menurun tingkat kecemasan pasien preoperasi dengan nilai R Spearman -0,854, penerapan komunikasi efektif dokter-pasien pada pasien pre operasi di Paviliun Dahlia RSU.dr.H.Koesnadi terbanyak adalah cukup (52,5\%), tingkat kecemasan pasien pre operasi di Paviliun Dahlia RSU.dr.H.Koesnadi terbanyak tergolong sedang $(42,5 \%)$.

\section{DAFTAR PUSTAKA}

Azwar, A. 1993. Menjaga Mutu Pelayanan Kesehatan. Yayasan Penerbitan IkatanIndonesia : Jakarta.

Brown JS. 1995. Buku Ajar dan Atlas Bedah Minor. Penerbit EGC : Jakarta.

Fausiah, Fitri. Widuri, Julianti. 2007. Psikologi Abnormal : Klinis Dewasa. Jakarta : Penerbit Universitas Indonesia $\mathrm{UI}$ - press.

Graeff, J.A., Elder, J.P. and Booth E.M. 1996. Komunikasi untuk Kesehatan dan Perubahan Perilaku. Yogyakarta : Gadjah Mada University Press.

Guandi, J. 1989. Dokter dan Hukum. Penerbit Monella, Jakarta.

Hacker.S., dkk. 2004. Comunicating With Patients.advise for Medical Praktitioner National Health and Medical Research Counsil Austarlian Government.

Hanafiah, MJ,.Amir,.A . 1999. Etika Kedokteran dan Hukum Kesehatan, cetakan ketiga. Penerbit buku kedokteran,EGC. Jakarta.

Harold, I.Kaplan \& Benjamin, J. Sadock.1997. Sinopsis Psikiatri Jilid 2. Jakarta : Binarupa Aksara.

Hawari D. 2001. Manajemen Stress, Cemas dan Depresi. FKUI. Jakarta.

Hoffman.D.V. 1997. Preparation For Surgery: Doktor's Nurse Can Be Negligent

for Faulty Explanation Of Procedur.

Iskandar Y. 2002. Stres, Anxietas dan Penampilan, Edisi ke satu. Yayasan Dharma Graha, Jakarta. pp. 34

Kaplan H.I., Sadock B.J. 2002. Ilmu Kedokteran Jiwa Darurat. Jakarta. Widya Medika. pp. 145

Kaplan H.I., Sadock B.J., Grebb J.A. 2002. Sinopsis Psikiatri : Ilmu Pengetahuan Perilaku Psikiatri Klinis. edisi tujuh jilid 2. Bina Rupa Aksara : Jakarta.

Kartono K. 2002. Psikologi Perempuan. Mandar Maju : Bandung.

Konsil Kedokteran Indonesia. 2006 .Manual Komunikasi Efektif Dokter-pasien. Jakarata.KKI

Kusuma, Widjaja. 2005. Dari A sampai Z Kedaruratan Psikiatrik dalam Praktek. Professional Books : Jakarta.

Liliweri, A. 2007. Dasar-Dasar Komunikasi Kesebatan. PustakaPelajar: Yogyakarta.

Lubis, Namora Lumongga. 2009. Depresi Tinjauan Psikologis, Edisi Pertama, Cetakan 1. Kencana Prenada Media Group : Jakarta.

Maramis, W.F. 2005. Catatan Ilmu Kedokteran Jiwa Cetakan IX. Surabaya. Universitas Airlangga. pp. 251-52, 258.

Mulayadi, .B. 1997. Hak dan Kewajiban Pasien, Dokter dan Rumah Sakit, Deprtemen Kesehatan RI, Direktorat Jendral Pelayanan Medis Jakarta.
Muzahan. F. 2007. Sosiologi Kesehatan. Jakarta. Universitas Indonesia Press.

Northouse, P.G. and Northouse, L.L. 1992. Health Communication Strategies forn Health Professionals. Second Edition. Norwalk, Connecticut : Appleton \& Lange.

Notoatmodjo S. 2005. Pengantar Pendidikan Kesehatan Dan Ilmu Perilaku Kesehatan. Andi Offset : Yogyakarta.

Rakhmat, J . 2007. Psikologi Komunikasi. Edisi Revisi. PT. Remaja Rosdakarya : Bandung.

Richar,W, Turner.LH. 2007. Introducing Commnunikation Theor: Analisis and Aplication. McGraw-Hill 121 Avenue of Americas,NY,10020.

Rini. 2006. Hubungan Tingkat ecemasan dengan Propil Tekanan Darah pada Pasien Pre Operasi Tur of Prostat di Instalasi Bedah Sentral RSUD.Dr.Moewardi Surakarta.

Sastroasmoro.S.I. 1995. Dasar - dasar Metodologi penelitian klinis, cetakan pertama,Bina Rupa Aksara.

Smet, B. 2002. Psikologi Kesehatan. Gramedia : Jakarta. pp. 26 Soetjiningsih. 2008. Modul komunikasi pasien-dokter: suatu pendekatan holistik. Jakarta : ECG.

Suliswati. 2005. Konsep Dasar Keperawatan Jiwa, EGC, Jakarta. pp. $42-43$.

Suryabrata, S. 2002. Psikologi Kepribadian. Raja Grafindo Persada : Jakarta. pp. 55-56.

Suryono. 2008. Legal formal Hubunggan Profesional DokterPasien, di sampaikan dalam Seminar Ikatan Dokter Gigi Indonesia Cabang Sleman. Yoyakarta 26 juli 2008.

Schlenker,BR.,M.R. Leary,D.R. Forsith \& R.S. Miller.1980.Self Presentational Analysis Of the effect of Incentives on Attitude Change Following Counterattitudional Behavior. Jurnal of Personaliti and Sociliati Psykology.Vol.39.No.4.hal 553-557.

Stuart \& Sundeen. 2001. Buku Ajar Keperawatan Jiwa Edisi 3. EGC : Jakarta.pp. 311.

Stuart, W, Gail, 2007, Buku Saku Keperawatan Jiwa Edisi 5, EGC, Jakarta. pp. 102.

Tanjung. 2005. Efek Komunikasi Terapeutik terhadap Tingkat Kecemasan Pasien Pre Operasi di Rumah Sakit Haji Adam Malik.

Triana. 2010. Hubungan antara Pengetahuan tentang Penyakit Jantung Koroner (PJK) terhadap Tingkat Kecemasan Pasien PJK di RuangRawat Inap RSU.dr.H.Koesnadi Bondowoso.

Tubbs, S.L. Terjemah Mulyana, D. 2000. Human Communication : Prinsip- Prinsip Dasar. Edisi ke-1. Bandung : PT. Remaja Rosdakarya.

Utama H. 2010. Buku Ajar Psikiatri . Badan Penerbit FK UI : Jakarta.

Veronica Komalawati.1999. Peranan Informed Consent dalam Transaksi Terapentik. PT. Cipta Aditya Bhakti: Bandung.

Williams J.R. 2005. Medical Ethics Manual Ethics Unit of the World Medical Association.

Wheeler.R. 2006. consent in surgery. the royal collage of surgeon of England. 